\title{
nombalina
}

(8)

\section{Intertextualidade e metaficção em Fantasia para dois coronéis e uma piscina, de} Mário de Carvalho

\author{
Autor(es): $\quad$ Santos, Rosana Baptista dos \\ Publicado por: Imprensa da Universidade de Coimbra \\ URL \\ persistente: URI:http://hdl.handle.net/10316.2/37027 \\ DOI: $\quad$ DOI:http://dx.doi.org/10.14195/978-989-26-0548-7_7 \\ Accessed : $\quad$ 26-Apr-2023 15:50:59
}

A navegação consulta e descarregamento dos títulos inseridos nas Bibliotecas Digitais UC Digitalis, UC Pombalina e UC Impactum, pressupõem a aceitação plena e sem reservas dos Termos e Condições de Uso destas Bibliotecas Digitais, disponíveis em https://digitalis.uc.pt/pt-pt/termos.

Conforme exposto nos referidos Termos e Condições de Uso, o descarregamento de títulos de acesso restrito requer uma licença válida de autorização devendo o utilizador aceder ao(s) documento(s) a partir de um endereço de IP da instituição detentora da supramencionada licença.

Ao utilizador é apenas permitido o descarregamento para uso pessoal, pelo que o emprego do(s) título(s) descarregado(s) para outro fim, designadamente comercial, carece de autorização do respetivo autor ou editor da obra.

Na medida em que todas as obras da UC Digitalis se encontram protegidas pelo Código do Direito de Autor e Direitos Conexos e demais legislação aplicável, toda a cópia, parcial ou total, deste documento, nos casos em que é legalmente admitida, deverá conter ou fazer-se acompanhar por este aviso.

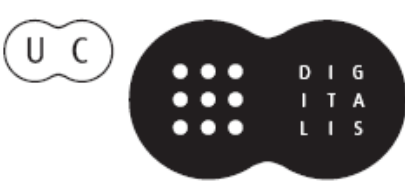


do Tempo e da História

- Mário de Carvalho e a reflexáo metaficcional sobre o futuro do romance - Sátiva e o cepticismo: configuração de personagens em Mário de Carvalho - Escrever tem arte e tem segredos... Era bom que trocássemos umas ideias sobre o assunto - O processo criativo em Era bom que trocássemos umas ideias sobre o assunto - Intertextualidade e metaficção em Fantasia para dois Coronéis e uma Piscina, de Mário de Carvalho - Trimalquiāo, os coronéis e a piscina: retrato impiedoso de um pais em crise $\bullet A$ Paixão do Conde de Fróis: paródia e subversão • "Como dizia o outro": a presença dos Clássicos em Mário de Carvalho - Cultura Clássica em Um

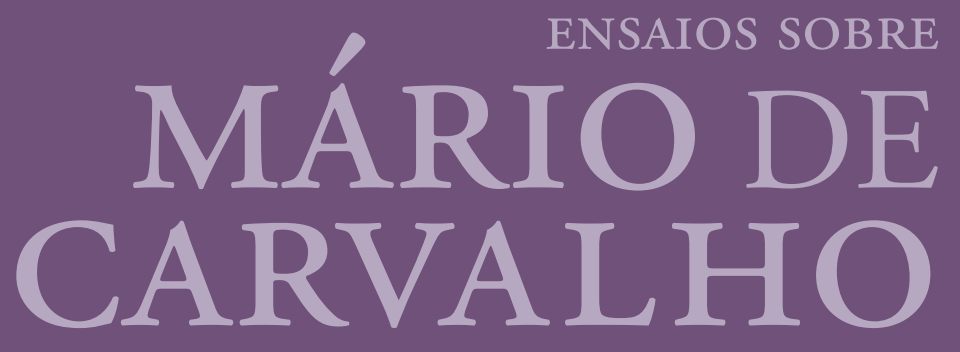

Maria de Fátima Silva Tereza Virgínia Ribeiro Barbosa COORD. IMPRENSA DA UNIVERSIDADE DE COIMBRA COIMBRA UNIVERSITY PRESS

elemento mouro como simbolo de alteridade $e$ barbárie em Um deus passeando pela brisa da 


\title{
Intertextualidade e Metaficção em Fantasia para dois Coronéis e uma Piscina, de Mário de Carvalho
}

\author{
Rosana Baptista dos Santos \\ Universidade Federal de Lavras
}


(Página deixada propositadamente em branco) 
Através da ironia ${ }^{1}$ e da paródia, ${ }^{2}$ o romance Fantasia para dois coronéis e uma piscina ${ }^{3}$ procura representar as particularidades (sobretudo as negativas) da sociedade portuguesa contemporânea. O termo "fantasia", que consta do título, refere-se aos vários eventos extraordinários que dominam a narrativa e instauram um ritmo próprio do sonho e da ilusão. Construído como um "mosaico de citaçôes", ${ }_{4}$ o romance procura estabelecer uma relação entre os textos clássicos greco-latinos, a tradição literária portuguesa e a narrativa contemporânea, por meio de referências diretas e indiretas a vários autores como Homero, Aristóteles, Petrônio, Camões dentre outros; e, também, a temas e estruturas próprias da tradição literária greco-latina, como o apelo à Musa, a estratégia da aparição inesperada de um deus ex machina, a sobreposição de diferentes narrativas, a demonstraçấo dos "bastidores" da criação artística e o diálogo com o leitor. Essa narrativa que acolhe diversos outros "géneros de escrita - novela, crónica, cinema e até poesia" ${ }^{5}$-, é classificada pelo autor de cronovelema, ${ }^{6}$ na medida em que "procurou ser um desconcertante festival de ilusionismo". O termo cronovelema é, também, um neologismo de inspiração clássica que exprime a idéia de uma "viagem literária pelo tempo". Tal sentido é evidenciado no episódio em que simultaneamente uma personagem percorre os campos portugueses à procura de um determinado tiroteio, enquanto o narrador, que se denomina autor, e o leitor, repetidamente convocado a também "viajar", "deslizam" para outro local a fim de observarem outro personagem.

* Agradeço à Capes (Coordenação de Aperfeiçoamento Pessoal de Nível Superior) pela concessão de uma bolsa de Doutorado Sanduíche para a realização da pesquisa sobre a obra de Mário de Carvalho, na Universidade de Coimbra, que resultou na publicação deste capítulo de livro.

1 Cf. o estudo de Hutcheon, L. (2000), Teoria e Politica da Ironia. Traduçâo de Julio Jeha. Belo Horizonte, Editora UFMG; Xavier, L. G. (2007), O discurso da ironia. Lisboa, Novo Imbondeiro.

2 Cf. definição de paródia em Sant’Anna, A. R. (1985), Parodia, paráfrase \& cia. 2. ed. São Paulo, Ática; Hutcheon, L. (1989), Uma teoria da paródia. Lisboa, Edições 70.

3 Carvalho, M. ('2004), Fantasia para dois coronéis e uma piscina. Lisboa, Caminho. Em 2004, este romance obteve o Prémio de Novelística do Pen Clube Português, patrocinado pelo Instituto Português do Livro e das Bibliotecas.

4 O termo é usado por J. Kristeva ao tratar da Intertextualidade. Cf. (1974ª), Introdução à semanálise. São Paulo, Perspectiva: 64.

5 Carvalho, M., (2003), "Mário de Carvalho: crónica do aturdimento”. JL-Jornal de Letras, Artes e Ideias 864, 12/11: 12. Entrevista de Maria João Martins. Vide também os vários versos e trechos de música inseridos no romance, 21, 48, 54, 131, 132, 218.

6 Vide Fantasia para dois coronéis e uma piscina, 34. 
Assim declara o narrador: “(... ) nós cada vez o ouvimos mais sumido, vamo-nos afastando, desliza Portugal (...) com vagar” (34). Pode-se depreender dessa passagem a noçáo de criaçáo literária como um afastamento do real, e de imaginação como elemento que propicia uma visão abrangente, englobadora das diversas realidades. Narrador e leitor cessam de ouvir os sons próximos, concretos e reais, para "voarem sobre Portugal". É a partir daí que, finalmente, dotados de todos os elementos que controlam, porque voam sobre eles, partem em uma espécie de "odisseia" da imaginação, num modelar Renault Quatro, o carro mais comum dos portugueses na década de sessenta. Neste sentido, o tema da "viagem" nesta obra literária é concebido numa dupla acepçáo: a primeira metafórica, como uma forma imagética de mencionar as coordenadas da criação; a segunda como suporte estruturante, intradiegético, do texto. De fato, é a estruturação da narrativa em vários patamares, o entrecruzamento destes planos narrativos e a simultaneidade dramática que permitem essa dinâmica cinematográfica, sempre guiada por "viajantes do vocabulário, da semântica e da real fantasia" (19).

Há preocupações com certos aspectos da criação literária que são, em Mário de Carvalho, centrais e aludidos com insistência. Quando o autor-narrador trata da composição narrativa, por exemplo, indica-nos o objetivo do romance, que "propóe-se a narrar" (34). Essa ação de narrar demandaria "o seu tempo e os seus tempos" (34), o que significa dizer que há um tempo específico para a concepção da obra de arte e os tempos da ação que compóem a narrativa, cuja multiplicidade vincula-se a própria estrutura do romance.7 Segundo D’Onofrio, o romance "é constituído por um complexo de valores temporais, em que se implicam o tempo do narrador, o tempo do relato e o tempo do leitor". ${ }^{8}$ Assim, um dos elementos fundamentais da narrativa é, sobretudo, a composição (e a manipulação) do tempo, um fator que permite um caráter demiúrgico assumido pelo autor. ${ }^{9}$ Entretanto, não se pode desprezar a importância do narrador como condutor da trama narrativa e, certamente, do tempo. Ilustra esta questão de forma modelar o romance Era bom que trocássemos umas ideias sobre o

7 Uma das características que distinguiria o romance do conto é a variedade do tempo. Cf. Moisés, M. ('1973), A criação literária: introdução à Problemática da Literatura. São Paulo, Melhoramentos: 195-226.

8 D’Onofrio, S. (1978), Poema e Narrativa: estruturas. São Paulo: Duas Cidades: 73.

9 Cf. Moisés 1973: 196. 
assunto, ${ }^{10}$ de Mário de Carvalho, no qual o autor-narrador coloca-se como um verdadeiro Criador, que se "beneficiando do tempo narrativo" (105), detém uma visão global sobre o tema, sempre "à mão do autor totalitário" (94). É por isso que declara: "Deslizo cá do meu Olimpo e instalo-me por ali, naquela sala pelintra, talvez junto ao canto superior esquerdo, encostado ao tecto, do lado da empena, que é sítio azado para tudo ver, pese embora a mancha da humildade" (114). Para se obter uma visão totalizadora da narrativa e manter um controle sobre os fatos narrados é imprescindível convocar um narrador heterodiegético, porque, como ele mesmo afirma, "um narrador omnisciente tem as suas vantagens. Se o narrador não fosse omnisciente náo saberia deste particular (...)" (35). Evidentemente, o tempo e o tipo de narrador escolhidos intervirăo no "pacto de verossimilhança" que deve haver entre o autor e o seu leitor. A literatura não tem, é óbvio, um compromisso com a verdade, no entanto os fatos narrados possuem uma equivalência de verdade, uma mimesis comprometida com a verossimilhança, ou com qualquer propriedade do "poder acontecer". ${ }^{11}$ Aqui ela é entendida pelo autor-narrador como um instrumento de controle da fantasia: "o que eu passo a contar agora é inacreditável. Prossigo a custo, após uma perplexa hesitação. A vida, não raro, ficciona, devaneia, absurdiza e eu hei-de conformar-me a ela, mais do que ao famoso pacto de verosimilhança outorgado com o leitor" (84). Certamente, essa é uma inversão irônica do entendimento sobre o processo de criação literária, na medida em que é a literatura que "representa" a vida; é ela que ficciona, devaneia e absurdiza.

Embora esse romance seja um texto contemporâneo, o processo de junção de elementos utilizados pelo autor não é novo, ao contrário, remonta a estratégias próprias e constantes na literatura grega; é particularmente sugestivo, pela própria reflexão que faz sobre esta estratégia, o romance de Luciano de Samósata e, numa vertente mais próxima de influência, a obra de Almeida Garrett. Em História Verdadeira, ${ }^{12}$ de Luciano, tal como ocorre em Fantasia para dois coronéis e uma piscina, percebemos uma voz narrativa

10 Carvalho, M. (52003), Era bom que trocássemos umas ideias sobre o assunto. Lisboa, Caminho. Embora este romance não faça parte do nosso corpus, pensamos ser importante ressaltar algumas questôes do âmbito da teoria literária, freqüentemente aludidas, nele, pelo autor. Sobre este assunto, vide supra

11 Cf. D’Onófrio 1978: 15. Para o autor, há dois tipos de verossimilhança: a interna e a externa. A primeira está relacionada à coerência dos elementos que estruturam a narrativa; a segunda diz respeito ao "bom senso e opinião comum". Se o texto não tiver uma verossimilhança externa, é porque ele está no campo do gênero fantástico.

12 Vide supra ... 
claramente metaficcional, que se intitula como autor e anuncia que seu texto nos seduzirá não somente porque o tema seja estranho, ou porque narrou mentiras diversas com ar de verossimilhança, mas sim por "à laia de paródia, cada passo da narrativa fazer alusão a certos poetas, prosadores e filósofos, que nos deixaram obras fantásticas e cheias de imaginação"13 (I. 2); afirma ainda que virou-se para a mentira, "mas uma mentira mais desculpável que a daqueles, porquanto numa coisa serei eu verdadeiro: ao confessar que minto" (I. 4). Aos vários autores que escreveram histórias fantásticas ou charlatanices, assegura que "serviu de guia e mestre (...) o Ulisses de Homero que impingiu aos Feaces narrativas de ventos enclausurados, de Ciclopes de um só olho, de homens que se alimentavam de homens, de animais bicéfalos e transformação dos seus companheiros em animais através de drogas" (I. 3). Nessa exortação inicial, o objetivo da viagem narrada é atribuído a vaidade humana, garante o autor: "eu, por vanglória, resolvi deixar à posteridade qualquer coisa do género, só para não ser o único a não beneficiar da faculdade de contar histórias fantásticas" (I. 4). A afirmativa garante ao leitor que o romance náo privilegia a verdade e sim o deleite, o entretenimento, embora faça consideraçóes filosóficas e estéticas. ${ }^{14}$

$\mathrm{Na}$ literatura de expressão portuguesa, dentre vários exemplos possíveis desse tipo de estratégia narrativa com a qual se pode relacionar o romance de Mário de Carvalho, destacamos a de Almeida Garrett, Viagens na minha Terra: ${ }^{15}$ o texto retoma as consideraçóes metaficcionais à maneira de Luciano, levando-as ao limite, e colocando em cena um autor-narrador irônico que, dialogando com o leitor, conduz a narrativa sempre expondo

13 Nickel, R. (1999), "Lucian's True Story: impressions of a fancy voyage”. Euphrosyne 27, 249/257: 250. Para o crítico, “é possível reconhecer os antecedentes literários mencionados por Luciano em alguns pontos. Todavia, há razóes para acreditar que Luciano não atribuía grande importância à possibilidade de identificação dos modelos literários de sua paródia pelos leitores".

14 Luciano mostra-se surpreso pelo fato de outros autores pensarem que suas "mentiras" não seriam notadas: "Em face de toda esta produção, não verberarei por aí além os seus autores, porquanto verificava que tal era entáo habitual, mesmo entre os que faziam profissão de filósofos. Uma coisa, no entanto, me espantava neles: o facto de cuidarem que as mentiras que escreviam passariam despercebidas". (I. 4)

15 Cf. Garrett, A. (1973), Viagens na minha Terra. Rio de Janeiro, Editora Três: 44. Neste romance, o narrador chega a dar uma receita de como facilmente se pode construir um romance: "Todo o drama e todo o romance precisa de: uma ou duas damas, um pai, dois ou três filhos, de dezenove a trinta anos, um criado velho, um monstro, encarregado de fazer as maldades, vários tratantes, e algumas pessoas capazes para intermédios". 
ao interlocutor as estruturas da criação literária e as várias relações textuais que o romance estabelece, ${ }^{16}$ ainda que não haja eventos fantásticos.

Assumindo uma composição semelhante a do texto de Luciano e de Garrett, a narrativa de Mário de Carvalho prioriza tanto o receptor quanto os elementos que compóem o romance, numa espécie de retomada das características da sátira menipéia que ambos os autores adotam. ${ }^{17}$ Dessa forma, o autor-narrador nos guia constantemente não só através de vários espaços portugueses, para o "bastidor da criação literária", mas também a outros textos a que recorre para compor sua narrativa. Os acontecimentos fantásticos (ou insólitos e sobrenaturais) que tomam a obra, ou a vida de Emanuel, convertem-se "em trampolim metafórico de uma crítica social". ${ }^{18}$

Já no início do romance, no episódio em que os dois coronéis discutem sobre uma ideal composição literária, há uma referência à questão da intertextualidade, quando um dos personagens pergunta ao outro de forma irônica: " - E as piscadelas de olho? Há gajos que se fartam de fazer citaçóes encapotadas só para ver se a malta dá por isso!” (16). Desprezando o fato de que todo o texto refere-se a outros textos, o coronel entende que os autores fazem citações apenas para testarem os leitores desavisados. Para o outro personagem, as referências são apenas labirintos, enigmas que se impóem ao leitor: "- Peneiras... Charadices..." (16). É evidente a ironia das afirmações, pois o romance a todo instante evoca direta ou indiretamente outros

16 Cf. uma análise mais detalhada desta questão em Pereira, E. (2003), "Viagens na minha terra: ciladas da representação". Revista do Centro de Estudos Portugueses 23 n. 32: 61-68.

17 Sobre a obra de Luciano, veja-se o estudo de Brandão, J. L. (2001), A poética do Hipocentauro: Literatura, sociedade e discurso ficcional em Luciano de Samósata. Belo Horizonte, Editora UFMG. Cf. também Bakthin, M. (1981), Problemas da poética de Dostoievski. Tradução de Paulo Bezerra. Rio de Janeiro, Ed. Forense-Universitária: 97-103. O autor elenca quatorze características da tradição da sátira menipéia, dentre as quais salientamos as seguintes: o aumento do peso específico do elemento cômico, embora esse peso seja flexível nas diversas obras; total liberdade de invenção temática e filosófica; a fantasia não serve à materialização da verdade, mas à busca, à provocação e principalmente à experimentação dessa verdade. Por isso os heróis sobem aos céus, erram por países fantásticos. O fantástico assume caráter de aventura. O conteúdo da menipéia é a aventura da idéia ou da verdade no mundo; combinação orgânica do fantástico livre e do simbolismo e, às vezes, do elemento místico-religioso com o naturalismo de submundo extremado e grosseiro (do nosso ponto de vista). As aventuras na terra ocorrem nas grandes estradas, nos bordéis, nos covis de ladrốes, nas tabernas, nas feiras, prisôes, orgias eróticas dos cultos secretos, etc. Aqui a idéia não teme o ambiente do submundo nem a lama da vida; uso do Fantástico experimental: observação feita de um ângulo de visão inusitado (do céu, por exemplo); a existência dos gêneros intercalados.

18 Schwartz, J. (1981), Murilo Rubião: A poética do Uroboro. São Paulo, Editora Ática: 77 
textos; entretanto, há aqui uma menção ao leitor que é digna de nota: é ele quem deverá articular as diversas citaçóes "encapotadas" que compóem o romance, determinando seus sentidos.

Das várias formas que o autor utiliza para referir outros textos, chamamos a atençáo para o recurso usado pelo tio de Emanuel, que se intromete no enredo para pedir ao narrador que proteja o sobrinho (93). Ele assume usar um expediente intertextual de forma explícita, cuja estratégia é a indicação dos mitos que retoma: "De cada vez, sou sempre forçado a calcar a estrada macerada de pedras da fábula. A figura de Sísifo também serve, mas eu nunca desafiei os deuses, nem cometi as tropelias do outro" (89). Dito de outra forma, o personagem utiliza a figura do mito, porém o adéqua a história, suprimindo elementos que pensa serem desnecessários.

É habitual no romance, também, a tática intertextual que explicita os textos literários a que se recorreu para compor determinada cena. Esse é o caso da citação direta de um episódio do Satyricon, de Petrónio. ${ }^{19}$ Vejamos:

O coronel nunca tinha lido Petrónio, porque o romano nunca se ocupou de coisas militares, e naquele instante em que contemplava a grandeza quase infinita de seus domínios náo podia saber que um tal Trimalquião já tinha procedido a um raciocínio aparentado, mas na horizontal, à uma, por se encontrar deitado, à outra, por considerar apenas o caminho terrestre entre Roma e África. (125).

A Cena Trimalchionis, protagonizada por Trimalquião, é um episódio central do romance de Petrônio, que evidencia os excessos de um "novo rico". Isto significa que os pensamentos do coronel o aproximam do personagem da Cena, já que pensava ser proprietário de um espaço que ia "até aos confins do Universo" (125), idéia que anteriormente passara pela cabeça de Trimalquião ${ }^{20}$. Ao enumerar aos convivas suas múltiplas riquezas, o anfitriâo da Cena admite ter o desejo de possuir terras suficientes para unir a Sicília à África:

19 Usamos a tradução de Bianchet, S. B. (2004), Petrônio. Satyricon. Edição bilíngüe. Belo Horizonte, Crisálida.

20 É interessante ressaltar o princípio da "cronologia relativa” que Mário de Carvalho considera um fator obrigatório na disciplina criativa: "A grande diferença é que, se tivesse calhado, o coronel poderia saber alguma coisa sobre Trimalquião, mas Trimalquião nunca poderia sequer imaginar o coronel ...” (125). 
Graças aos Deuses, eu não compro nada, mas tudo isso que agora dá água na boca de vocês vem de uma propriedade minha que eu ainda não conheci. Dizem que é vizinha à de Tarracina e à de Tarento. Agora eu quero unir a Sicília a minhas pequenas propriedades, para que, quando eu tiver vontade de ir à África, navegue pelos limites de minha propriedade. $(48,2-3)$.

Para além do diálogo intertextual, as demonstraçóes excessivas de posses e de poder dos personagens, sobretudo de Trimalquiáo, indicam uma certa falta de refinamento e os exageros de um 'novo rico', que se deslumbra com a posição financeira agora assumida.

No romance Era bom que trocássemos umas ideias sobre o assunto, o narrador, do mesmo modo, indica como podem ocorrer as relaçóes entre os textos. Por meio de um personagem que se encontra com o tio, um professor de grego, o autor demonstra outras formas de intertextualidade: é que o jovem, mesmo não tendo lido as obras, as menciona por meio da leitura de enciclopédias, dicionários ou revistas.

O fulano é engenheiro de sistemas, mas, este, garanto que nunca leu um único romance na vida! Tinha decorado aquelas frases de qualquer álbum, ou enciclopédia, e estava ali, no Gambrinus, a debitá-las, em voz de papo, para toda a gente ouvir. E eu, que li tudo, e reli, calado que nem um rato. (...) Se lhe tivesse dado para o Tucídides, que eu tenho anotado parágrafo a parágrafo, o resultado era o mesmo: ele a brilhar, e eu a engolir em seco. (156)

O que se pode depreender do episódio é que, na verdade, há dois tipos de atitude na aquisição de fontes, que Mário de Carvalho distingue com argúcia: uma precisa, resultante de uma leitura séria, aprofundada, específica (ler, sublinhar, anotar), e outra superficial, de acaso, que permite "fazer figura", mas não tem solidez (157). Importa-nos esta questão, pois, como Jenny, ${ }^{21}$ entendemos que a intertextualidade tem implicações com o "funcionamento" da literatura, ou seja, de forma direta ou indireta um

21 Jenny, L. (1979), "A estratégia da forma”. Poétique. Revista de teoria e análise literárias. Traduçấo de Clara C. Rocha. Coimbra: Almedina, 05/49: 7. 
texto sempre se relaciona com outro texto através da paródia, da imitação, da alusão, da citação ou mesmo da crítica. ${ }^{22}$ Explica-nos Otte ${ }^{23}$ que:

O fragmento em si, implantado com uma aparente arbitrariedade no novo con/texto, o interrompe, provocando um "choque" de distanciamento devido à sua singularidade. No entanto, é o próprio estranhamento que impele o leitor quanto o historiador à procura do parentesco escondido na 'bagagem' do fragmento, ou seja, à descoberta da verdadeira proximidade. (OTTE 1996: 218)

Embora algumas citaçóes do romance ou referências a outros textos possam parecer inseridas de forma aleatória, a verdade é que provocam um estranhamento inicial no leitor, e é esse mesmo estranhamento (e reconhecimento) que proporciona pistas para a compreensão das relaçôes entre os textos e, é claro, da própria obra. Todas estas estratégias de intertextualidade que mencionamos são manipuladas por Mário de Carvalho em Fantasia para dois coronéis e uma piscina. Assim, fazemos nossa a definição de romance grego de Brandáo para nomear o romance de Mário de Carvalho: "o romance é escrita desatada e enciclopédia de gêneros". ${ }^{24}$

\section{Os distintos componentes de uma obra literária}

Em relação às reflexóes metaficcionais ${ }^{25}$ que perpassam todo o romance Fantasia para dois coronéis e uma piscina, chamamos a atenção para a primeira discussão, com caráter introdutório, sobre literatura, que vem à tona através dos coronéis Bernardes e Lencastre, num debate sobre a estrutura do romance que a esposa de Bernardes lia: O Apicultor e o Bidão de Mel. Passemos às consideraçóes literárias que fazem os personagens. Para o Coronel Bernardes, aquela narrativa era:

22 Cf. a crítica que o autor faz a obra de Paulo Coelho, 66.

23 Otte, G. (1996), "Rememoração e citação em Walter Benjamin”. Revista de Estudos de Literatura 4. Belo Horizonte, Centro de Estudos Literários (CEL), Faculdade de Letras da UFMG, 211/223: 218.

24 Brandão 2005: 216. Grifo do autor.

25 Para uma análise da metalinguagem, veja-se o texto de Perrone-Moisés, L. (1979), "A intertextualidade crítica". Poétique. Revista de teoria e análise literárias. Tradução de Clara C. Rocha. Coimbra, Almedina: 209-230. 
(...) perdas de tempo, deambulaçôes, opinióes, descrições, filosofias, desarrumação... um bocejo, pá. Eu cá para mim, um livro deve apressar-se para o evento, começar logo a meio da coisa e eliminar os desvios e as imaginações que só servem para encher. Um homem com pescoço de cavalo, por exemplo (...) (15-16)

Retomando as consideraçôes da Arte Poética de Horácio ${ }^{26}$ quase na íntegra, o personagem, em tom irônico, critica exatamente as características do texto do qual faz parte, que é composto justamente por desvios, deambulaçôes, descriçôes, desarrumação e opiniōes diversas. Por meio da descrição de um ser híbrido, Horácio (1-37) defende a idéia de que a verossimilhança deve ser buscada tanto pelo pintor quanto pelo poeta. Por isso, recrimina aqueles que náo atendem ao princípio da unidade e da simplicidade do poema (23), comparando as digressóes em um texto a um "remendo purpúreo" costurado a um pano diferente, que formará um todo sem harmonia. Embora os personagens do romance defendam uma estratégia narrativa que se apresse para o evento, para a ação, esta tática não será seguida pelo autor do romance do qual os coronéis são protagonistas; ao contrário, o texto caracteriza-se pela falta de coesão e de simplicidade.

Seguindo a mesma linha de preferência do amigo, o coronel Lencastre também recorre a uma teorização antiga, agora a da Poética de Aristóteles, para definir o que seria uma estrutura narrativa adequada. Apontando para os componentes do texto literário (como a ação, os personagens, os pensamentos, o ritmo $)^{27}$ e sua hierarquia, assim se manifesta o personagem:

26 Cf. Horácio, Arte Poética 1-37: "Se um pintor quisesse juntar a uma cabeça humana pescoço de cavalo e a membros de animais de toda a ordem aplicar plumas variegadas, de forma que terminasse em torpe e negro peixe a mulher de bela face, conteríeis vós o riso, ó meus amigos, se a ver tal espetáculo vos levassem? (...) Geralmente a princípios solenes e onde se prometem grandes coisas, para obter mais efeito, qualquer remendo purpúreo se lhes cose (...) Em suma: faz tudo o que quiseres, contando que o faças com simplicidade e unidade".

27 Sobre a definiçẫo de tragédia, das partes e dos elementos essenciais, Aristóteles afirma que o elemento mais importante da tragédia é "a trama dos fatos (...) Sem ação não poderia haver tragédia", Poética 1450 a 16-23. A imitação de uma ação se "executa mediante personagens e que diversamente se apresentam (...)", 1450 a 35. Já o pensamento “é aquilo em que a pessoa demonstra que algo é ou não é, ou enuncia uma sentença geral”, 1450 b 4. A elocução é definida como "o enunciado dos pensamentos por meio das palavras", 1450 b 12, 1456 a, 1456 b e 1457 b. A "toada” ou melopéia é considerada pelo autor como “o principal ornamento", 1450 b 15. Em relação ao "espetáculo cénico, decerto é o mais emocionante, mas também o menos artístico e menos próprio da poesia. (...) a realização 
(...) o mais importante é o entrecho, a acção. Depois vêm as personagens e respectivo desenho moral. A seguir, o pensamento, os conceitos. Mas também a maneira como está escrito, o português, se é bom ou mau. Há ainda a toada, o ritmo, que é importante. Finalmente, o modo como os acontecimentos são postos diante dos nossos olhos, a ... como hei-de dizer? A espectacularidade da coisa (...). (16)

Essas consideraçóes do personagem (estipuladas através de uma ordem de prioridades) fazem parte de uma espécie de jogo irônico realizado pelo autor ao longo do texto, pois o coronel não lia um romance há trinta anos (16), nem seria versado em teoria literária; logo náo estaria apto a tratar do assunto. Praticamente todas as características assinaladas e elogiadas pelos personagens serão contrariadas pelo autor ao longo da narrativa. De acordo com Compagnon, "a atitude dos literatos diante da teoria lembra a doutrina da dupla vertente na teologia católica. Para seus adeptos, a teoria é ao mesmo tempo objeto de fé e uma apostasia: crê-se nela, mas não inteiramente". ${ }^{28}$ Essa parece ser a postura do autor de Fantasia para dois coronéis e uma piscina.

\section{2. $\mathrm{O}$ enredo}

Ao tratar do enredo, o Coronel Bernardes defende a exclusão do acessório, dos desvios e da imaginação (15), em nome de um fio narrativo claro e coeso: "Deve dizer-se logo o que tem de ser dito, e pôr os pormenores de lado, não achas?" (16), pergunta ao amigo. Deste modo, defende um texto que narre os fatos considerados prioritários, omitindo os elementos

de um bom espetáculo mais depende do cenógrafo que do poeta”, 1450 b 16. Sobre as relaçóes entre os fatos no enredo afirma o seguinte: "Homero, assim como se distingue em tudo o mais, também parece ter visto bem, fosse por arte ou por engenho natural, pois, ao compor a Odisseia, não poetou todos os sucessos da vida de Ulisses (...) mas compôs em torno de uma ação una a Odisseia, _ una, no sentido que damos a esta palavra, e de modo semelhante a Ilíada. (...) Por conseguinte, tal como é necessário que nas demais artes miméticas una seja a imitação, quando o seja de um objeto uno, assim também o mito, porque é imitação de açóes, deve imitar as que sejam unas e completas, e todos os acontecimentos se devem suceder em conexão tal que, uma vez suprimido ou deslocado um deles, também se confunda ou mude a ordem do todo. Pois não faz parte de um todo, o que, quer seja quer não seja, não altera esse todo", 1451 a 22,1451 a 29.

28 Cf. Compagnon, A. (2001) O demônio da teoria: Literatura e sendo comum. Belo Horizonte, Editora UFMG: 258. 
indesejáveis (os desvios e a imaginação). Também o narrador de Era bom que trocássemos umas idéias sobre o assunto ilustra o que seria "o indesejável acessório" em uma narrativa, ou seja, o que não está intimamente relacionado ao enredo: "(...) mas, francamente, acho que estas personagens não merecem que se faça o jeito e o leitor há-se ser poupado àquilo de que não precisa, porque, tal como eu, se está nas tintas para as emblemáticas comerciais" (82). Para Lencastre, é necessária uma coesão entre os elementos do texto, de forma que ao se retirar algum componente, o conjunto não resista: “- Pois para mim, os factos devem estar numa tal relaçáo que, suprimido ou deslocado um deles, também o conjunto se transforme ou confunda. $\mathrm{O}$ que se pode acrescentar ou tirar sem conseqüências, não faz parte do todo" (16), ou ainda, em decorrência "de linear e límpida causalidade" provêm resultados de "carácter imediato e muito prático" (43). No elogio da unidade de ação e da supressão dos desvios, evoca-se a máxima latina in medias res ("no meio dos acontecimentos"), utilizada por Horácio em sua Arte Poética (148), como a estratégia adequada para iniciar uma narrativa. Esta deve assumir como ponto de partida um momento adiantado do desenvolvimento da ação, e não os fatos iniciais do enredo. Por meio da analepse, os eventos excluídos do princípio da ação serão recuperados numa fase posterior do romance. ${ }^{29}$ No caso da epopéia grega, a primeira a utilizar esta tática na literatura ocidental, embora a disposição dos fatos não obedeça a uma ordem linear, o enredo não perde em verossimilhança; ao contrário, este recurso cria uma dinâmica narrativa extremamente ágil, tanto que a analepse (ou o flash-back) é hoje amplamente explorada pelo cinema como uma tática que permite uma agilidade maior a narrativa fílmica. Este recurso é valorizado tanto no em Fantasia para dois coronéis e uma piscina, quanto em Era bom que trocássemos umas idéias sobre o assunto. No primeiro romance, a ação inicia já com os coronéis morando no campo e em torno da piscina (12-16); os fatos anteriores só serão retomados posteriormente; no entanto, a cena inicial dos coronéis discutindo sobre literatura será recuperada quase na íntegra ao final do romance (207). Em Era bom, o autor-narrador defende abertamente a narrativa que inicia in medias res e o flash-back ao afirmar que: "Os cineastas - deslembrados de Homero ou Camóes - estão candidamente convencidos de que foi o cinema que inventou a analepse, a que chamam flash-back. E até há alguns que manifestam animadversão contra

29 Cf. Il. 1.9 sqq. e Od. 1.11 sqq. Camôes, em Os Lusíadas, segue o modelo épico tradicional, começando a narrativa sobre a viagem de Vasco da Gama in medias res. Cf. 1. 19 sqq. "Já no largo Oceano navegavam, As inquietas ondas apartando (...)". 
os flash-backs (...) E vem a tal analepse para contar o que se passou momentos antes (...)" (21). Seguindo esta estratégia, o cronovelema é estruturado como uma espécie de "filme em forma de romance, em que a narrativa é apresentada numa sucessão de planos, sugerindo-se a movimentação de câmara, como se os vários espaços, tempos e personagens que desfilam nesta Fantasia estivessem a ser projectados num ecrã". ${ }^{30}$

Para eliminarem-se desvios e deambulações desnecessárias, a tragédia conta com um componente importante, o Prólogo. De acordo com Aristóteles (Poética 1452b 18), "Prólogo é uma parte completa da tragédia, que precede a entrada do côro", e que executa um papel coordenador, que antecipa e ordena a narrativa. Este tipo de introdução, que também antecede alguns episódios de Fantasia para dois coronéis e uma piscina, que aqui se faz ouvir pela voz do narrador, e não dos atores como ocorre na tragédia, é utilizado pelo autor (na esteira dos escritores clássicos) para se dirigir aos leitores a fim de ironizar algumas situaçóes, pedir benevolência ao "experiente leitor", ou fazer consideraçóes sobre a composição do próprio romance. ${ }^{31}$ Dessa forma, o "prólogo" desta Fantasia nem sempre cumpre a função de antecipar os eventos do enredo, como afirma o próprio narrador: "Algo ficámos já a saber do que importa, mas náo tudo" (34); essa falta de visão geral sobre a ação, muito explorada na tragédia grega do séc. v. a. C. como um fator de suspense, contraria o ensinamento aristotélico, na medida em que estimula as digressóes do narrador. Temendo que a previsibilidade das ações do enredo (ditadas por um 'Prólogo') tornasse os leitores "desatentos”, já que as conheceriam previamente, o autor-narrador lança mão do elemento surpresa, que pode advir de uma quebra na esperada coesão da estrutura da narrativa. Essa tática náo corresponde aos ensinamentos de Aristóteles, embora fosse comum no teatro grego.

O procedimento de anular a ilusão cênica é retomado neste romance em vários pontos da narrativa, mas uma das passagens mais sugestivas é a que transcrevemos abaixo, quando o narrador discute com o leitor sua estratégia narrativa:

Tentaçáo enorme, ó experiente leitor, de parar aqui e mudar de foco. Fazer actuar o efeito de deferimento. Emanuel estarrecido, sem pinga de sangue, por onde andarão os cães horrendos? E mudar de capítulo,

30 Mendes, A. M. G. (2005), "Trimalquião, os coronéis e a piscina: retrato impiedoso de um país em crise". Ágora. Estudos Clássicos em Debate. Aveiro 7, 129/150: 229-130.

31 Às vezes, a chave para a antecipação dos fatos é um breve: "Pois assim se resume" (36). 
passar para São Jorge do Alardo, ou Lisboa, e o leitor ansioso, a procurar nas páginas mais adiante, a querer saber se Emanuel foi estraçalhado pelos cães, ou se lhe apareceu, pendurada ao alto, aquela figura divina e providencial que costuma desviar-lhe os caminhos. Mas eu não sou um escriba manipulador, especioso em ganchos, chif-hangings e outros artifícios para prender a atenção do narratário. Vozes se levantarão contra os meus processos tão cristalinos de limpidez e boa intenção. Eu sou franco, náo há arcas encouradas, digo logo tudo. (60-61)

A ironia da afirmativa reside no contraste entre as características defendidas pelo narrador e como de fato ele conduz a narrativa. Na verdade, ele é realmente um manipulador nada cristalino e muito mal intencionado, que renuncia a todas as convençóes para compor um texto que, para além das açóes, centra-se em sua própria constituição fragmentada. Essas intromissóes do narrador no enredo e as conversas com o leitor e com os personagens nos remetem às teorizaçóes de Adorno (1983) sobre a posiçáo do narrador no romance contemporâneo. Segundo o teórico, o narrador investe contra um componente essencial "na sua relação com o leitor: a distância estética. Esta era inamovível no romance tradicional. Agora ela varia como as posiçóes da câmara no cinema: ora o leitor é deixado de fora, ora guiado (...) até o palco, para trás dos bastidores, para a casa das máquinas". ${ }^{32}$

Com um "Posso?"33 (80), um outro personagem, tio de Emanuel, interrompe a história sobre os coronéis, pois, segundo ele, essa era uma ótima ocasiáo para entrar na narrativa e deixar uma mensagem para o parente, um andarilho difícil de ser encontrado (80). Havia pensado em colocar um anúncio no jornal, assegura, mas esta era uma alternativa cara e da qual não se podia ter garantias de sucesso. Este é um exemplo dessa mesma quebra de ilusão, que parece ser do gosto de uma certa narrativa contemporânea: "De resto, esta é uma narrativa contemporânea - acho eu - que desconfia dos acasos e das causalidades manipuladas...” (82). Através da afirmativa podemos inferir que no romance contemporâneo não há coincidências; os

32 Adorno, T. W. ( $\left.{ }^{2} 1983\right)$, "Posição do narrador no romance contemporâneo". In: Benjamin, Honkheimer, Adorno, Habermas. Tradução de José L. Grünnewald et al. São Paulo, Abril Cultural, 269/273: 272.

33 Esta é uma estratégia próxima da chamada 'quebra da ilusão cênica' - ou seja, de fazer saltar uma personagem da cena, ou retirá-la da intriga, e pô-la a dialogar diretamente com o público - que é muito vulgar na comédia grega. Cf. e.g. Aristófanes, Acarnenses 628 sq., Nuvens 535, 1115 sq., 1121, Paz 629, Aves 1101, 1114. 
eventos não são dispostos gratuitamente no texto, ao contrário, correspondem a um tipo de construção textual que se volta sobre si mesma.

Por meio desses diálogos com o narratário, da intercalação de narrativas variadas e do diálogo irônico com o leitor, o narrador destrói a tranqüilidade contemplativa do leitor diante do que lê, como se pode perceber através do seguinte comentário do autor-narrador: "Um dia, leitor, hei-de contar as ânsias e os tormentos com que se vai martelando esta artesania da escrita, em que ainda sobrevive a mão do caldeireiro ou, talvez do fazedor de autômatos (...)" (216). O que esse autor-narrador faz é desnudar aos olhos do leitor a forma como se constrói um texto ficcional, que é realizado sempre por meio de uma labuta constante, não necessariamente bem paga (216).

\section{A composição do personagem}

Um enredo coeso e regular exige do autor uma cuidadosa criação dos personagens e de seus respectivos desenhos morais, pois eles são portadores das idéias que sustentam a narrativa. Aristóteles (Poética 1448b 4) foi o primeiro a teorizar sobre o personagem ao assegurar que "imitar é congênito ao homem (...) e os homens se comprazem no imitado". Tanto nos textos narrativos quanto nos teatrais, o personagem é o componente essencial através do qual o enredo se desenvolve, ou seja, "as personagens constituem os suportes vivos da ação e os veículos das idéias que povoam uma narrativa”. ${ }^{34}$ Não raro alguns personagens, por causa de suas características ideológicas, morais ou mesmo físicas, podem ser considerados como modelo de determinados comportamentos. Assim, a criação do personagem no romance pode ocorrer pela generalização dos traços, como a que acontece com Emanuel Elói: "É daquelas figuras que inspira simpatia e confiança a um primeiro olhar, mesmo de longe" (14). Ou mesmo pode haver um desmontar de uma identidade pessoal para se obter um modelo; este é o caso da descrição do Coronel Bernardes, que é, afinal, um exemplo da classe a que pertence: "Como é sabido, os militares oficiais superiores são, entre os cidadãos que compóem uma vasta classe média, os mais ampla e diversificadamente relacionados." (64). A construção da piscina é o meio pelo qual a articulação entre as diferentes personagens ocorrerá, pois, através dela, "havia uma universal vontade de ajudar", "reatou-se a cadeia de solidariedade, numa teia de malhas estreitas que cobria e apertava Portugal

34 D’Onofrio 1978: 62. 
de sul a norte"35 (65). É importante mencionar a identificação dos tipos humanos dispostos a auxiliar o coronel na empreitada: "Há uma multidão de capitáes, majores, brigadeiros, engenheiros, médicos, professores, que estão ávidos por ajudar" (64). É como se fosse o país inteiro a se movimentar para executar essa tarefa, já que a piscina tem a mesma forma de Portugal. É neste contexto que um importante personagem, Emanuel, surgirá: ele é "vedor de águas", um técnico que o major Linhares Beira indica para trabalhar para o coronel Bernardes (66).

É pelo nome 'falante' que inicialmente se define esse personagem. O próprio Emanuel explica a escolha de seu nome:

- O meu pai quis dar-me um nome benigno e abençoado e fez uma lista de que constavam os seguintes: 'Eloim, Adonai, Sadai, Soter, Emanuel, Sabahot, Tetragrammaron, Alpha e Omega, Principium et Finis, Hagios, Ischiros, Otheos, Athanatos, Agla, Jehova, Homonsion, Ya, Iesus Christós, Messias, Elva, Elrei...' Mas o empregado do Registro civil só aceitou Emanuel. (67)

No Evangelho de Mateus, o nome Emanuel é mencionado para designar o filho de Deus que nasceria: "Tudo isto aconteceu para que se cumprisse o que foi dito da parte do Senhor, pelo profeta, que diz: Eis que a virgem conceberá e dará à luz um filho, e chamá-lo-ão pelo nome de Emanuel, que traduzido é: Deus conosco". ${ }^{36} \mathrm{O}$ retrato que se pinta de Emanuel relaciona-se, certamente, a algumas características do próprio Cristo, que o ideário cristáo consagrou como o dom da caridade, a bondade e a quem atribuiu o

35 No romance Era bom que trocássemos umas idéias sobre o assunto, o autor tece diversas consideraçóes sobre os personagens. As relaçôes entre os personagens são explicadas pelo narrador: "Eduarda tem um destino a cumprir e eu arranjarei maneira de a integrar na história" (59). Por isso, o narrador articula as histórias dos personagens: "E assim se estabeleceu o contacto entre Eduarda Galvão e Jorge Carreira Matos, aprestando-se uma ligação nesta história que já nela tardava" (67); e constrói o retrato psicológico dos mesmos, embora afirme não querer entrar em detalhes: "Eu não queria entrar muito em pormenores psicológicos, porque tenho pressa, e prometi não aprofundar em excesso esta figura, mas talvez não seja despiciendo sublinhar aquilo que já está percebido" (61). Em relação às atitudes das personagens, afirma que é necessário que haja alguma sobriedade em sua descrição para que não seja muito extensa: "um escritor estilista dedicaria umas boas três páginas a descrevê-la, com gestos, saltos, risinhos, urros e queda de unidades" (85).

36 Biblia Sagrada, Mateus. 1, 22. Cf. também Isaías. 7,14: "Portanto, o mesmo Senhor vos dará um sinal: eis que uma virgem conceberá, e dará à luz um filho, e será o seu nome Emanuel". 
hábito de andar pelas cidades pregando seus ensinamentos e curando doentes: "percorria Jesus toda a Galiléia, ensinando nas suas sinagogas (...)". ${ }^{77}$ Emanuel também é descrito como um "moço jeitoso que anda sempre bem disposto. Ele é andarilho, gosta de bem fazer, meteu-se pelo país numa carrinha Renault Quatro" (81); durante as viagens, sempre se preocupava com os outros, como quando pára a viagem para ajudar o Apicultor de mel (14); ou quando cura um marinheiro do navio Telos que sofria de escorbuto (116). Não é por acaso que o caráter e as atitudes do personagem estão em consonância com o próprio nome: "chama-se Emanuel Elói, ${ }^{38}$ é uma bondade de moço, trotamundos, e tem algum jeito e muita paciência para os seus conterrâneos" (14); afinal, estas sáo as atitudes esperadas de um "Deus conosco". Agindo de forma abnegada para com o próximo, Emanuel demonstra um certo desapego pelos bens materiais, que se traduz em seu próprio aspecto físico (14). O personagem parece seguir os ensinamentos de Cristo, para que não se ajunte "tesouros na terra, onde a traça e a ferrugem tudo consomem, e onde os ladróes minam e roubam", ${ }^{39}$ pois o único bem material que tem é seu velho Renault Quatro, com o qual viaja tanto por Portugal quanto por lugares fantásticos. Os termos usados para qualificá-lo (como bondade, paciência, benignidade, piedade) estão no mesmo campo de significado com o qual se qualificava Cristo, tanto que Maria das Dores sentia que havia algo diferente no rapaz: "Haver mais bonitos moços, há, mas este tem o seu quê, palavra de honra" (70). Neste sentido, o autor atentou para os ensinamentos aristotélicos, segundo os quais deve haver uma certa coerência na composição dos personagens; assim, o caráter, as idéias e as atitudes do jovem estão de acordo com sua aparência física, como fica evidente na seguinte descrição: "alto, desengonçado, com um cabelo espigado, às farripas, e uma cara agaitada, de traquinice benigna, não ficava mal na paisagem" (66). Talvez seja por causa destas características que Emanuel fosse "um eleito muito especial do destino e favorito de uma caterva de deuses que seria fastidioso enumerar" (45).

Como recurso metaficcional, o autor-narrador convoca Maria das Dores e Maria José, as esposas dos coronéis, para uma conversa "em cena" (175-187) sobre os papéis desempenhados por estas mulheres, numa espécie de apreciação crítica sobre a estrutura e agentes da ficção contemporânea.

\footnotetext{
37 Mateus. 4, 23. Veja-se, também, as andanças de Jesus no Evangelho de São Marcos.

38 Marcos. 15, 34: “(...) Jesus exclamou com grande voz dizendo: Eloí, Elóí (...) que traduzido é: Deus meu, Deus meu (...)”

39 Mateus. 6, 19.
} 
É principalmente através deste diálogo que passamos a conhecer alguns pormenores das personagens.

A esposa de Lencastre não possui um papel relevante no enredo, embora se relacione com os outros personagens da intriga; à Maria José Lencastre, o autor-narrador dispensa, mesmo assim, alguma atenção, chamando-a para uma conversa. A intenção do autor é que a personagem não ficasse "tão apagada nesta história" (176); por isso dá-lhe oportunidade para que faça os comentários que achar importantes. Diante da negativa da figura em continuar o diálogo, o narrador a adverte: "não vai depois recriminar-me por lhe ter dado pouca atenção? Veja lá...” (178); esta é certamente uma inversão irônica de papéis, pois quem determina o que acontece no romance é o autor. Porém, de acordo com Lopes, "mesmo quando o autor se arroga o papel do ditador, se a obra existe (sic.) ela resiste a essa arrogância". ${ }^{40}$

$\mathrm{O}$ autor estabelece um claro contraste entre as duas mulheres. Em relação aos nomes, à Maria José é dado o nome completo, com vários sobrenomes "Campos de Sousa e Lencastre" (176); "Adoptou o nome do marido, não foi? Na altura não era obrigatório" (176). Através do nome, percebe-se que é uma mulher secundarizada e dependente do marido. Já Maria das Dores é o contrário: não diz o nome completo ao narrador, não usa sobrenomes do marido, o que lhe reforça o individualismo e autoconfiança (182). Maria José, como figura secundária e apagada que é, tem uma atitude tímida: procura não responder às perguntas que lhe faz o autor, tenta sair de cena, fala laconicamente sobre si mesma, mas alarga-se na descrição da suas relaçóes com as outras personagens, o que é a própria justificação de uma personagem secundária (175-178). Maria das Dores, ao contrário, como personagem de relevo, centra seu discurso sobre sua própria figura, justificando sua atuação e detendo-se em seus traços principais: o discurso e o adultério (182-187). De forma diferente da vizinha, Maria José nunca freqüentou um colégio como o de Odivelas (176), mas um liceu normal; formou-se no tempo certo, deu aulas, seguiu o marido, namorou às escondidas, ou seja, há uma diluição de traços e a construção de uma figura vulgar (completamente ao contrário da Maria das Dores, a começar pelos estudos no colégio de Odivelas). O contraste explícito entre as duas personagens é sublinhado por Maria José no texto que prepara o diálogo que vem a seguir entre o autor e a segunda mulher: “(...) somos de geraçóes diferentes, ela é mais nova, mais... desinibida. Usa uma linguagem que não liga muito com o meu estilo. É mandona, menina rica, está toda envaidecida por estar a fazer a tese" (177).

40 Lopes, S. R. (2003), A defesa do Atrito. Viseu, Edições Vendaval: 31-32. 
O tom da conversa com Maria das Dores é outro: a personagem, dotada de um caráter dominador e auto-suficiente, garante que náo deve nada ao narrador e pede para terminar a conversa, ao que ele responde:

Com certeza, por quem é. Até não é impossível que aconteça outra coisa. Imagine que eu a suprimo de todo desta história. Posso sempre voltar ao princípio e prescindir da Maria das Dores. Faço o Bernardes viúvo, ou celibatário, caso-o com outra, amigo-o com uma desconhecida... e duvido muito que outro autor se interesse por ela. (183)

Com esta clara alusão ao poder que detém o autor de compor, transformar, misturar, suprimir algum elemento ou personagem de seu texto, o narrador ressalta uma importante questáo para os estudos literários: a estrutura textual. Ao ser questionada pelo narrador sobre o porquê de sua "convocaçáo", a personagem, em tom de desprezo, responde que são "efeitozinhos estilosos. Farófias" (186). A respeito deste episódio, em que se discute abertamente a construçáo do texto, ressaltamos a afirmativa de Hutcheon ${ }^{41}$ de que a necessidade do romance moderno em pensar sua própria constituição evidencia o interesse de parodiar, que é essencial no gênero narrativo desde sua origem, o que demonstra tanto uma pretensão de produzir ficções quanto de admitir seu caráter fictício. ${ }^{42}$

Retornemos a atençáo para o desenho das personagens femininas no romance português que nos ocupa. Defendendo o texto que privilegie uma ação una, despida de digressóes inúteis, Lencastre ressalta a necessidade de se criar uma personagem dotada de harmonia de traços. A referência a esta característica é extremamente contraditória, pois Maria das Dores, esposa do coronel Maciel Bernardes e uma das personagens principais, representa a transgressão desta desejável harmonia: embora seja uma mulher erudita, possui uma linguagem que não se adequa ao resto do retrato; "falava (...) destemperadamente, não dissimulava, nem se esforçava por isso" (30). Apesar desta linguagem vulgar, era formada em História da Arte, e no momento elaborava uma tese de mestrado intitulada $O$ traje feminino entre os povos originários da Lusitânia Tarrogonense, que seria apresentada na Universidade de Évora (32). Além disso, havia estudado no respeitável Colégio de Odivelas, "lia livros, sabia descascar e comer pêssegos, não

41 Hutcheon, L. (1977), "Modes et formes du narcisisme littéraire”. Poétique 29: 90-106.

42 Esta mesma estratégia de colocar em cena uma crítica literária é um elemento marcante no teatro grego, na tragédia e, ainda de forma mais explícita, na comédia. 
usava talher nos aspargos e, no entanto, exprimia-se destarte. O coronel já desistira de lhe explicar que não ficava bem dizer 'não me fodam' às mulheres dos outros oficiais, a meio dum jogo de canastra" (29); assim, o desenho social de Maria das Dores é incompatível com seus outros predicados. Por isso seu nome muda também, e o marido passa a tratá-la, ironicamente, por $A$ Baronesa (23). $\mathrm{O}$ apodo, na verdade, não era elogioso, ao contrário, fora-lhe dado após a descoberta de uma traição ao marido, que agora a chamava por um apelido "carregado de um veneno esverdeado, fétido, capaz de fulminar à distância" (31). Pode ser sugestivo, entre as figuras femininas do teatro antigo com as quais podemos relacionar a Baronesa, destacar a de Fedra, personagem do Hipólito, ${ }^{43}$ de Eurípides, por causa da ousadia das figuras que transgridem o código moral da sociedade em que vivem e, também, pelo próprio discurso que ambas proferem em defesa de seus atos. Inquirida pelo narrador sobre sua maneira de falar, a própria personagem do romance tem a possibilidade de justificar seus atos, embora ironize a situação ao afirmar que não deve satisfaçóes ao autor (183), por uma estratégia semelhante, ao colocar em cena uma dupla de personagens que, além de agir com total liberdade, analisam seus próprios atos e motivaçóes. A voz da interlocutora de Fedra, a Ama, é substituída pela voz do autor-narrador que indaga Maria das Dores sobre o motivo do adultério que comete. Tanto a rhesis de Fedra como a de Maria das Dores têm como cerne o tema do adultério e a condição feminina. $\mathrm{O}$ que difere nos seus discursos é que Fedra procura se manter afastada desta "tentação vulgar na mulher" 44 , pois "como mulher, sabia-o bem, era para todos objeto de ódio" (405-407); Maria das Dores, igualmente, critica o que pensa ser uma posição machista do autor, e por extensão do mundo em que vive: "É evidente que sempre me tratou às três pancadas. Os machos absorvem toda a sua atenção. Você não percebe peva de mulheres nem quer perceber" ${ }^{\prime 35}$ (186). A personagem explica sua "tendência" ao adultério como uma "vontade de enredo, vontade de mistério, vontade de variar, vontade de encher o paiol" (185). Ou seja, a Baronesa não traía o marido porque se apaixonava por outros homens, mas simplesmente pelo gosto de colecionar, porque era "aditiva", afirma (185), o que demonstra um total desprezo pelo moralismo (e machismo) da sociedade a que pertence (185).

43 Utilizamos a tradução de Oliveira, B. S. (1997), Eurípides. Hipólito. Brasília, Editora UNB.

44 Silva 2005: 182.

45 Cf. a questão da dimensão dada à personagem em Ar. Rãs v. 1059-1062. 
Por meio de um discurso argumentativo, tal qual o dos retores clássicos e da própria Fedra, a personagem relativiza a ética habitual até o ponto em que o respeito aos sentimentos do marido passa a náo ter nenhuma importância. Neste sentido, seu comportamento imoral é coerente com a linguagem "desbragada" que utilizava, ou mais precisamente, a palavra (logos) coincide com a açáo (pragma); embora seu impulso natural (physis) não esteja de acordo com a convenção social (nomos) da sociedade em que vive. ${ }^{46}$ No que diz respeito à proporção palavra-ação, há que ter cuidado com a "teatralidade" de uma personagem: "Essas coisas, num texto, não se dizem. Mostram-se" (186-187), garante o narrador.

É importante mencionar também o tio de Emanuel, que conviveu com o Nelson Lencastre desde pequeno: ele é um personagem secundário que pede licença ao autor-narrador para entrar em cena. Seu nome não é mencionado, porque segundo ele: "o meu nome náo interessa. Sou o tio dos bigodes torcidos e do casaco de tweed, e infelizmente as minhas qualidades são habitualmente apreciadas de modo assaz superficial" (82). Parece haver a tipificaçáo de um modelo de personagem - "o tio" -, com a sua caracterização, sobretudo, exterior. Embora sua dimensão seja mais apagada que a de outros personagens, ele contribui para a definição das outras figuras mais relevantes, como por exemplo, a de Emanuel. Sobre esse personagem, que é tratado como um 'mensageiro', há aspectos a valorizar: até que ponto, por exemplo, o mensageiro é apenas uma testemunha do que relata, ou um interveniente ativo; ou que relação tem com a figura sobre a qual se pronuncia. Quando menciona Nelson, o 'tio' demonstra que teve um contato direto com o personagem, pelas referências à infância dos dois: "brinquei com o Nelson em miúdo"; "acho que sei mais dele (...)"; "ainda me recordo" (80); "nós brincávamos"; "me feri ... borbotei ... sobrevivi"; "impressionava-me" (81). Em contraste com o que sabe sobre o Nelson, do sobrinho o 'tio' pouco sabe: "não sei o número do telemóvel" (81); "não tenho forma de o contactar" (81-82); "já pensei em pôr um anúncio no jornal” (82). Parece claro que o contacto com os dois se fez em tempos diferentes e em circunstâncias distintas.

46 Aos comentários intradiegéticos, feitos pelas personagens, o autor associa a voz dos críticos externos, aqueles que para a dissonância da personagem encontram sutis razóes psicológicas; faz-se também uma curiosa conexão com estratégias cinematográficas, numa confluência de processos entre as diversas formas de mimesis (o que Aristóteles também sugere na Poética). 
É também do "mensageiro" a estratégia de abrir a narrativa imediata a outros tempos e a outros contextos (80), intervindo em momentos em que não há ação. Interessa-nos, pois, o tipo de discurso que profere e o estilo que usa, com mençóes explícitas a termos da linguagem retórica. Segundo Perelman, o objetivo da argumentação não é provar uma verdade ou chegar a uma conclusão e, sim, conseguir a adesão do interlocutor; ${ }^{47}$ é exatamente a adesão do sobrinho à sua tese que visa o discurso do tio de Emanuel. $\mathrm{Na}$ primeira referência que o personagem faz sobre a linguagem retórica que utiliza, chama a atenção para "o árduo e consabido exercício da memória" (85). Explica-nos Lausberg, que a elaboração do discurso argumentativo pressupóe cinco fases: inventio, dispositio, elocutio, memoria e pronuntiatio. ${ }^{48}$ Ainda segundo o mesmo autor, a inventio não é o próprio processo de criação, mas "como encontrar um meio da recordação: os pensamentos (...) já existem, no subconsciente do orador (...) e só precisam ser despertados por uma hábil técnica mnemónica (...)" ${ }^{49}$ A memoria consistiria da memorização do discurso, enquanto que a pronuntiatio é a própria "pronunciação de um discurso e dos gestos concomitantes". ${ }^{50} \mathrm{O}$ discurso do tio de Emanuel é extremamente misógino, afirma o narrador, e advoga a favor da "tese acerca das mulheres desencontradas" (88). Pode-se dizer que a estruturação de seu discurso argumentativo é contraditória, denuncia o narrador: primeiro, o personagem defende a "ênfase no discurso ao sobrinho", ou a memorização do mesmo (88); depois, "a premência do conteúdo dele" (88), já que o personagem garante que se pronuncia "pelos conteúdos" (87). Entretanto, seu desenho pouco nítido ou a estruturação de seu discurso de forma contraditória náo chegam a ser um problema no romance, pois o personagem é um ser de "papel", cujas posiçôes e atitudes podem se transformar a todo o momento justamente por seu caráter ficcional: aliás, ele só tem relevância na narrativa pelos discursos que profere.

Chamar à cena um personagem para discutir seu papel ou inserir um personagem que contesta o discurso dos outros é uma estratégia para mos-

47 Cf. Perelman, C. O. (1993), O Império Retórico: Retórica e Argumentação. Tradução de Fernando Trindade e Rui Alexandre Grácio. Porto, Edições Asa: 29.

48 Lausberg, H. ( $\left.{ }^{4} 1967\right)$, Elementos de Retórica Literária. Tradução e prefácio de R. M. Rosado Fernandes. Lisboa, Fundação Calouste Gulbenkian: 91. 49

49 Ibidem 1967: 91. 40. A dispositio é a "escolha e ordenação favoráveis ao partido, as quais, no discurso concreto se fazem dos pensamentos, das formulaçôes lingüísticas e das formas artísticas" (95. 46). Já a elocutio é “a expressão linguística dos pensamentos encontrados pela inventio" (115. 91).

50 Lausberg 1967: 93. 45. 
trar os artifícios ficcionais ao leitor; ao agir assim, essa literatura narcisista exige deste a mesma capacidade imaginativa utilizada no ato da criação; por isso o narrador chama o leitor de "experiente" (60): só um narratário atento e experimentado pode compreender melhor estes mecanismos da ficçáo moderna. O questionamento do narrador dá-nos conta deste dispositivo: "porque é que a vida não explica a si própria, como os romances?" (155). Este tema do "destinatário experiente" era muito comum na comédia grega. Aristófanes, por exemplo, mantém este tipo de diálogo com o público a propósito da competência criativa. Impulsionado pelo caráter competitivo das representaçóes teatrais, o poeta precisava agradar tanto ao público que o ouvia, quanto os juízes que julgariam a peça. ${ }^{51}$ Para tanto, eram comuns na parábase os apelos, elogios ou censuras dirigidos aos ouvintes, os louvores ao público ou ao próprio texto e mesmo a promessa de benefícios aos juízes. ${ }^{52}$ Assim, "por trás de toda esta variedade de reacçóes e atitudes está um único e primordial interesse: que o público acolha com benevolência o poeta e não se mostre parco em aplausos". ${ }^{33}$

Concluindo, importa ressaltar, a respeito das relaçóes entre os textos e as discussōes metaficcionais, a clara noção que tem o narrador sobre a constituição do romance, ou sobre como um texto é sempre contaminado por outro texto, da mesma forma que as palavras são contaminadas por outras. Podemos afirmar, entâo, que uma das questóes centrais tratadas pelo autor sobre a criaçáo literária é a impossibilidade de se conceber uma narrativa contemporânea totalmente autônoma, sem relação com a literatura (e a cultura) erigida ao longo da história da humanidade. Mesmo sendo autônomo e criativo, um texto moderno não pode (e não quer) negar sua relação com a tradição literária já existente.

51 Silva, M. F. S. (1987), Critica do teatro na Comédia Antiga. Coimbra, Fundação Calouste Gulbenkian: 24.

52 Dentre vários exemplos destes subterfúgios, cf. o elogio ao público "com bom gosto" em Aristófanes, Nuvens 521, 527; promessas de regalias aos juízes e de castigo se o prêmio não fosse concedido, Nuvens 1115-1121, Aves 1101-1114; auto-elogio, Acarnenses 628 sqq., Paz 734 sqq.

53 Silva 1987: 27. 


\section{Bibliografia Geral}


(Página deixada propositadamente em branco) 


\section{Ediçôes de Mário de Carvalho}

(21990), Contos da sétima esfera. Lisboa, Caminho.

(1991), Quatrocentos mil sestércios. Lisboa, Caminho.

(71991), Casos do beco das sardinheiras, Lisboa, Caminho.

(31993), A Paixão do Conde de Fróis. Lisboa, Caminho.

(1996), Os Alferes. Lisboa, Caminho.

( $\left.{ }^{3} 1996\right)$, O livro grande de Tebas, Navio e Mariana. Lisboa, Caminho.

(1997), Um deus passeando pela brisa da tarde, Lisboa, Caminho.

$\left({ }^{3} 1997\right)$, Fabulário. Lisboa, Caminho.

(52003), Era bom se trocássemos umas ideias sobre o assunto. Lisboa, Caminho.

(32004), Fantasia para dois Coronéis e uma Piscina. Lisboa, Caminho.

('2006), A inaudita guerra da Avenida Gago Coutinho. Lisboa, Caminho.

(2008), A sala magenta. Lisboa. Caminho.

(2010), A Arte de Morrer Longe. Lisboa, Caminho.

\section{Estudos}

Adorno, T. W. ('1983), "Posição do narrador no romance contemporâneo". In: Benjamin, Honkheimer, Adorno, Habermas. Trad. port. José L. Grünnewald et alii. São Paulo, Abril Cultural: 269-273.

Albaladejo, T. (1986), Teoría de los mundos posibiles y macroestructura narrativa. Alicante, Universidade de Alicante.

Albaladejo, T. (1992), Semántica de la narración: la ficción realista. Madrid, Taurus.

Albérès, R. M. (1972), Métamorphoses du roman. Paris, Albin Michel.

Almeida, J. F. (1997), Bíblia Sagrada. Rio de Janeiro, Fecomex (Ed. Revisada e corrigida).

Alves, C. C. (2010) "Vestígios do trágico em Mário de Carvalho”. Navegaçôes 3. 1: 53-58.

Anacleto, M. T. (1996), “(Sub)versions du "cliché” romanesque au XVII siècle: le "roman bourgeois" de Furetière”, Confluências 14: 97-109.

Angelini, P. R. K. (2011) "Recensão de Carvalho, M. A arte de morrer longe. Lisboa, Caminho, 2010. 128p.”. Navegaçōes 4. 1: 131-133.

Arnaut, A. P. (2001), "Donas e donzelas n'a Demanda do Santo Graal”, Santa Barbara Portuguese Studies. Califórnia, n. 5: 29-71. 
Aristófanes (21989), A Paz. Tradução de Silva. M. F. Coimbra, Instituto Nacional de Investigação Científica.

Aristófanes (2006), As Aves. Tradução de Silva, M. F. Lisboa, Edições 70.

Aristóteles (1986), Poética. Tradução de E. Sousa. Lisboa, Fundação Gulbenkian.

Arnaut, A. P. (2002), Post-Modernismo no romance português contemporâneo. Fios de Ariadnemáscaras de Proteu. Coimbra, Almedina.

Assis, A. K. T. (2008), Arquimedes, o centro de gravidade e a lei da alavanca. Montreal, Apeiron Montral.

Auerbach, E (1976), Mimesis (A representação da realidade na literatura ocidental). São Paulo, Perspetiva [1 $1^{\text {a }}$ ed., 1946].

Aurélio, Marco (1971), Pensamentos. Versão de João Maia. Lisboa, Editorial Verbo.

Bakhtine, M. (1970), La Poétique de Dostoievsky. Paris, Éd. du Seuil.

Bakhtine, M. (1981), Dialogic imagination: four essays. Austin, University of Texas Press.

Bakthine, M. (1981), Problemas da poética de Dostoievski. Trad. port. Paulo Bezerra. Rio de Janeiro, Ed. Forense-Universitária.

Benjamin, W. (1985), "Sobre o conceito de História. Tradução de Sérgio Paulo Rouanet”. In: Obras escolhidas. Magia e técnica, arte e política. São Paulo, Editora Brasiliense: 222-232.

Bessière, J. (2010), Le roman contemporain ou la problemacité du monde. Paris, PUF.

Beye, C. R. (1964), "Homeric battle narrative and catalogues", Harvard Studies in Classical Philology 68: 345-373.

Bergson, H. (2001), O riso: ensaio sobre a significação da comicidade. Trad. port. Ivone C. Benedetti. São Paulo, Martins Fontes.

Bhabha, H. K. (1998), O local da cultura. Belo Horizonte, Editora UFMG.

Bianchet, S. B. (2004), Petrônio. Satyricon. Edição bilíngüe. Belo Horizonte, Crisálida.

Bougnoux, D. (1991), "Le principe d'identification”. In Personnage et Histoire Littéraire. Toulouse, Presses Universitaires du Mirail: 187-195.

Brandão, J. L. (2001), A poética do Hipocentauro: Literatura, sociedade e discurso ficcional em Luciano de Samósata. Belo Horizonte, Ed. UFMG.

Brasete, M. F. (2003), “A crítica às mulheres no fr. 7 de Semónides de Amorgos”. In: Mora, C. M. (ed.), Sátira, Paródia e Caricatura: da Antiguidade aos nossos dias. Aveiro, Universidade de Aveiro: 39-56.

Brauner, E. F. (2009), “" Era bom que trocássemos umas ideias sobre o assunto”: ironia de um narrador e discussão do romance", Revista Electrónica de critica e teoria de literaturas. Dossiê: o romance português e o mundo contemporâneo 5. 2. Porto Alegre: 1-9.

Buescu, H. (1995), A Lua, a Literatura e o Mundo. Lisboa, Cosmos. 
Buescu, M. L. C. (1979), Aspectos da herança clássica na cultura portuguesa. Lisboa, Instituto de Cultura Portuguesa.

Camôes, L. (1979), Os Lusíadas. Prefácio de Hernâni Cidade. São Paulo, Abril Cultural.

Carcopino, J. (1993), La vida cotidiana en Roma en el apogeo del imperio, trad. esp. Madrid, Ediciones Temas de Hoy.

Cardoso Bernardes, J. A. (1988), O Bucolismo Português. A égloga do Renascimento e do maneirismo. Coimbra, Livraria Almedina.

Carvalho, M., (2003), "Mário de Carvalho: crónica do aturdimento". JL - Jornal de Letras, Artes e Ideias 864, 12/11: 12.

Ceia, C. (2007), A Construção do romance (Ensaios de literatura comparada no campo dos estudos anglo-portugueses). Coimbra, Almedina.

Chevalier, J., Gheerbrant, A. (1994), Dicionário dos Símbolos, trad. port., Lisboa, Editorial Teorema.

Colaço, J. (1995), “Mário de Carvalho”, Biblos. Enciclopédia verbo, I, s.u.

Compagnon, A. (2001), O demônio da teoria: Literatura e senso comum. Belo Horizonte, Editora UFMG.

Constâncio, N. (2007), Ruinas e incertezas em "Um Deus passeando pela brisa da tarde”, de Mário de Carvalho. Lisboa, Edições Colibri.

Costa, L. S. (1995), “Era Bom que Trocássemos Umas Ideias Sobre O Assunto, de Mário de Carvalho. A Arquitectura, A Violência”. In: Público/Leituras, 11 de Novembro:10.

Cotrim, J. P. (1996), Entrevista a Mário de Carvalho: "Alguma coisa me perturba”. Ler/Livros e Leitores 34: 45.

Cotrim, J.P. (1996), "Mário de Carvalho. O Mistério da Literatura”, entrevista ao autor. LER 34, Primavera.

Cristóbal, V. (1992), "Búsqueda de campo, hastío de ciudad. Pasión antigua y contemporánea”. In: Guzmán, A. et alii (ed.), Aspectos modernos de la Antigüedad y su aprovechamiento didáctico. Madrid, Ediciones Clásicas: 131-143.

Davison, M. (1976), "The thematic use of ekphrasis in the ancient novel”, in Erotica antiqua. Acta of the International Conference on the Ancient Novel. Bangor, ICAN: 32-33.

Devereux, G. (1975), Dreams in Greek tragedy. Oxford, Basil Blackwell.

Dijksterhuis, E. J. (1987), Archimedes. Translated by C. Dikshoorn. Princeton University Press.

Diogo, A. A. L. (1997), "Exórdio". In: Biblos- Enciclopédia Verbo das Literaturas de Lingua Portuguesa. Lisboa, São Paulo, Verbo.

D’Onofrio, S. (1978), Poema e Narrativa: estruturas. São Paulo, Duas Cidades. 
Duncan, T.S. (1935), “The deus ex machina in Greek Tragedy”. Philological Quarterly 14: $126-141$.

Dunn, F. M. (1985), Euripidian Endings: a Study of the Choral Exit, the Action, the Concluding Prophecy and the Deus ex Machina. Yale University: 111-167.

Eco, U. (1979), Leitura do Texto Literário. Lector in Fabula. Trad. Mário Brito. Lisboa, Presença.

Entrevista com Mário de Carvalho http://www.homemmag.pt/pt/index.php/arte-e-literatura/arquivo-arte-literatura/87-luisa-costa-gomes-entrevista-mario-de-carvalho

Ernout, A. ( $\left.{ }^{11} 1993\right)$, Pétrone. Le Satyricon. Paris, Les Belles Lettres.

Ernout A, Meillet, A. ( $\left.{ }^{4} 1967\right)$, Dictionnaire etymologique de la langue latine: histoire des mots. Paris, Librairie C. Klincksieck.

Errandonea, I. (1954), Diccionario del mundo clásico. Barcelona, Editorial Labor.

Eschilo ( $\left.{ }^{4} 2000\right)$ I sette contro Tebe. Con testo a fronte. Introd. Umberto Albini. Trad. Ezio Savino. Milano, Garzanti Editore.

Feijóo, B. (1998), Um Não Sei Quê. Lisboa, Vega [1746].

Ferreira, C. (2003), “Mário de Carvalho. A arte de bem iludir o leitor”. In: Rodapé: 45-51.

Ferreira, P. S. (1999), “A paródia e as suas implicações didácticas”. In: Torrão, J. M. N. (ed.), III Colóquio Clássico - Actas. Aveiro, Universidade de Aveiro: 113-137.

Ferreira, P. S. (2000), Os elementos paródicos no Satyricon de Petrónio e o seu significado. Lisboa, Colibri.

Ferreira, P. S. (2003), “Paródia ou paródias?”. In: Mora, C. M. (ed.), Sátira, Paródia e caricatura: da Antiguidade aos nossos dias. Aveiro, Universidade de Aveiro: 279-300.

Fialho, M. C. (1992), Luz e trevas no teatro de Sófocles. Coimbra, Instituto Nacional de Investigação Científica.

Figueiredo, M. N. (2006), "Com humana crueldade se tece um conto. A propósito de Homenagem ao Papagaio Verde”. In: Santos, G. (ed.) Jorge de Sena: Ressonâncias e Cinqüenta Poemas. Rio de Janeiro, 7Letras.

Fowler, D. P. ((1991), "Narrate and describe: the problem of ecphrasis", Journal of Rhetorical Studies 81: 25-35.

Frow, J. (1986), “Spectacle Binding: On Character”. Poetics Today 7. 2: 227-250.

Gaffiot, F. (1934), Dictionnarie Illustré Latin-Français. Paris, Librairie Hachette.

Garrett, A. (1973), Viagens na minha Terra. Rio de Janeiro, Editora Três.

Genette, G. (1972), Figures III. Paris, Ed. du Seuil.

Gennete, G. (1997), L'Cuvre de l'Art. La Relation Esthétique, II. Paris, Ed. du Seuil.

Genette, G. (2004), Métalepse. Paris, Ed. du Seuil.

Gomes da Torre, M. (1992), “Acerca da tradução da metáfora”. Linguas e Literaturas 9: 209-226. 
Grimal, P. (s/d), Dicionário de Mitologia Grega e Romana. Lisboa.

Guillén, J. (1977), Vrbs Roma - vida e costumbres de los romanos, vol. I: La vida privada. Salamanca, Ediciones Sígueme.

Guthrie, W. K. C. (1976), Les Sophistes. Paris, Payot.

Halliwell, S. (1968), Aristotle's Poetics. Chicago and London.

Hamon, P. (1976), “O que é a descrição?”. In: Seixo, M. A. (ed.), Categorias da narrativa. Lisboa, Arcádia: 61-83.

Hardwick, L. (2003), Reception Studies. Greece and Rome. New Surveys in the Classics. Oxford, Oxford University Press. [recensão do livro por Martin M. Winkler, in Bryan Mawr Classical Review 2004].

Heródoto. (2002), Histórias. Livro I. Tradução de Ferreira, J. R., Silva, M. F. Lisboa, Ediçóes 70. Heródoto (1997), Histórias. Livro III. Tradução de Silva, M. F., Abranches, C. Lisboa, Ediçóes 70. Heródoto (2000), Abranches, C., Histórias. Livro IV. Tradução de Silva, M. F., Abranches, Lisboa, Edições 70.

Homero (2003), Odisseia. Tradução de Frederico Lourenço. Lisboa, Livros Cotovia.

Homero (2005), Ilíada. Tradução de Frederico Lourenço. Lisboa, Livros Cotovia.

Hoorn, J. F., and Konijn, E. A. (2003), "Perceiving and experiencing fictional characters: An integrative account”. Japanese Psychological Research 45. 4: 250-268.

Horácio (1975), Arte Poética. Tradução de R. M. R. Fernandes. Lisboa, Clássica Editora.

Hutcheon, L. (1977), “Modes et formes du narcisisme littéraire”. Poétique 29: 90-106.

Hutcheon, L. (1984), Narcissistic Narrative. The Metafictional Paradox. New York and London, Methuen.

Hutcheon, L. (1985), A Theory of Parody. The Teachings of Twentieth Century Art Forms. New York \& London, Methuen; (1989), Uma teoria da paródia, trad. port. Lisboa, Ediçóes 70.

Hutcheon, L. (1988), A poetics of Postmodernism. History, Theory, Fiction. New York/London, Routledge; (1991), Poética do Pós-Modernismo. Trad. Ricardo Cruz. Rio de Janeiro, Imago.

Hutcheon, L. (2000), Teoria e Política da Ironia. Trad. port. Julio Jeha. Belo Horizonte, Editora UFMG.

Immerwahr, H. R. (1966), Form and thought in Herodotus. University of North Carolina.

Izaac, H. J. ( ${ }^{3} 1969$, 1973), Martial. Épigrammes, I-II. Paris, Les Belles Lettres.

Jauss, H. R. (1986), Experiencia y Hermeneutica Literaria. Ensayos en el campo de la experiencia estétca. Madrid, Taurus, [1977].

Jenny, L. (1979), "A estratégia da forma”, Poétique. Revista de teoria e análise literárias. Trad. port. Clara C. Rocha. Coimbra, Almedina: 5- 49. 
Jerome, K. J. , “Three men on the Brummel'. In: http://www.gutenberg.org/catalog/world/ readfilefk_files $=2061881$

Jourdan, P. (1996), "Paul Valéry chasseur de perroquets", Confluências 14: 51-59.

Júdice, N. (1997), Viagem por um século de Literatura Portuguesa. Lisboa, Relógio d'Água.

Julien, Y. (1998), Aule-Gelle. Les nuits attiques, IV. Paris, Les Belles Lettres.

Jurado, F. G. (1999), "Apuntes para una historia prohibida de la literatura latina en el siglo XX: La voz de los lectores no académicos”. In: Morán, M. C. A.; Iglesias Montiel, R. M. (eds.), Contemporaneidad de los clásicos en el umbral deI tercer milenio. Actas deI Congreso Internacional Contemporaneidad de los clásicos: La tradición greco-latina ante el siglo XXI. La Habana, Universidad de Murcia: 77-85.

Kerferd, G. B. (2003), O movimento sofista. Trad. port. Margarida Oliva. São Paulo, Ediçôes Loyola.

Kirk, D. M. (1960), The digression, its use in prose fiction from the Greek romance through the eighteenth century. Stanford University.

Kristeva, J. (1974ª), Introdução à semanálise. São Paulo, Perspectiva.

Kuester, M. (1992), Framing Truths - Parodic Structures in Contemporary English-Canadian Historical Novels. Toronto/London, Toronto University Press.

Lausberg, H. (1963), Elementos de retórica literária. Trad. port. Raul M. Rosado Fernandes, Lisboa, Gulbenkian.

Leão, D. F. (1996), “Trimalquião: a humanitas de um novo-rico”. Humanitas 48: 161-182.

Leão, D. F. (1997), “Trimalquião à luz dos Caracteres de Teofrasto”. Humanitas 49: 147-167.

Leão, D. F. (1998), As Ironias da Fortuna. Sátira e Moralidade no Satyricon de Petrónio. Lisboa, Colibri.

Leão, D. F. (2004), “Zoilo e Trimalquião, duas variaçôes sobre o tema do novo-rico”. Humanitas 56: 191-208.

Leão, D. F. (2004a), “O Satyricon de Petrónio e a crise dos paradigmas tradicionais”. In: Nascimento, A. (ed.), Antiguidade Clássica: Que fazer com este património?. Lisboa, Centro de Estudos Clássicos: 233-242.

Leão, D. F. (2005), Petrónio. Satyricon. Lisboa, Cotovia.

Lepaludier, L (2002), Métatextualité et métafiction. Théorie et analyses, Presses Universitaires de Rennes, CRILA.

Levi, P. (1988), É isto um homem? Rio de Janeiro, Rocco.

Lévy, E. (1983), "Le théâtre et le rêve: le rêve dans le théâtre d'Eschyle", in Zehnacker, H. (ed.), Théatre et spectacles dans l'Antiquité. Actes du Colloque de Strasbourg. Leiden: 141-168.

Lopes, S. R. (2003), Literatura, Defesa do atrito. Lisboa, Copiart. 
Lourenço, E. ('1982), "Da literatura como interpretação de Portugal”. In O Labirinto da Saudade (Psicanálise Mitica do Destino Português). Lisboa, D. Quixote: 85-126.

Lourenço, F. (2003), Homero. Odisseia. Lisboa, Cotovia.

Luciano (1996), Uma história verídica. Tradução de C. Magueijo. Lisboa, Editorial Inquérito Limitada.

Lukács, G. (1989), Théorie du roman. Paris, Flammarion [1916].

"Na Lusitânia com Mário de Carvalho (História, paródia e ironia em Quatrocentos mil sestércios e Um deus passeando pela brisa da tarde)". In Veredas 5 (2002) 211-224.

Macedo, A. G. (2008), Narrando o pós-moderno: reescritas, revisôes, adaptaçôes. Braga Universidade do Minho.

Machado, J. P. (1995), Dicionário etimológico da Língua Portuguesa. Lisboa, Livros Horizonte.

Malina D. (2002), Breaking the frame: metalepsis and the construction of the subject. Columbus, Ohio State UP.

Margolin, U. (2005), “Character”. In: Herman, D., Jahn M., Ryan, M.-L. (eds.), Routledge Enciclopedia of Narrative Theory. London/New York, Routledge: 54-57.

Marinho, M. F. (1996), "O sentido da história em Mário de Carvalho", Revista da Faculdade de Letras. Linguas e Literaturas: 257-267.

Marinho, M. F. (2010), "À la recheche de l'identité perdue. Essai sur la crise d'identité dans le roman portugais contemporain”. In: Besse, M. G. \& Ralle, M. (eds.), Les Grands Récits: Miroirs Brisés? Paris, Índigo:186-198.

Martin, F. (1987), Les mots latins. Paris, Hachette.

Martins, J. C. O. (2011), "Mário de Carvalho e a reflexão metaficcional sobre o futuro do romance”. Diacrítica. Dossiê Literatura e Religiāo 25/3: 23-44.

Martins, J. C. O. (2011), “Pensar Portugal - ironia, paródia e desencanto: Mário de Cavalho e o retrato melancólico de um país". In: Carvalho da Silva, J. A., Martins, J. C. O., Gonçalves, M. (eds.), Pensar a Literatura no Séc. XXI. Braga, Univ. Católica Portuguesa: 463-478.

Martins, J. C. O. (s.d.), "La barbarie de l'ignorance dans la culture postmoderne et la fiction de Mário de Carvalho". In: De l'Extrême: pratiques du contemporain dans les mondes ibériques et ibéro-américains, Paris, CRIMIC [em publicação].

Martins, M. F. (1983), Sombras e transparências da literature. Lisboa, INCM.

Martins, Maria João (2003), "Mário de Carvalho: crónica de um aturdimento" [entrevista], JL - Jornal de Letras, Artes e Ideias, no 864, 12 novembro, p. 12.

Mead, G. (1990), “The Representation of Fictional Character”. Style 24. 3: 440.

Medeiros, W. (1997), "Do desencanto à alegria: o Satyricon de Petrónio e o Satyricon de Fellini”. Humanitas 49: 169-175. 
Melanda, P. C. O. (2001), Pela mão de Clio. A reescrita da História em Mário de Carvalho. Aveiro. 38. Dissertação de Mestrado em Estudos Portugueses, apresentada à Universidade de Aveiro. Exemplar em CDRom.

Melero Bellido, A. (2001), "La utopia cómica o los límites de la democracia”, Cuadernos de Literatura Griega y Latina 3: 7-25.

Melero Bellido, A. (2004), "La lengua de la utopia". In: López Eire, A., Guerrera, A. R. (Eds.). Registros Lingüísticos en las lenguas clásicas. Salamanca, Ediciones Universidad Salamanca: 149-172.

Mendes, A. M. G. (1999), "Cultura clássica em Um Deus Passeando pela brisa da tarde de Mário de Carvalho”, III Colóquio Clássico - Actas, Aveiro: 347-363.

Mendes, A. M. G. (2005), “Trimalquião, os coronéis e a piscina: retrato impiedoso de um país em crise”. Ágora. Estudos Clássicos em Debate. Aveiro 7: 129-150.

Mendes, J. P. (1997), Construção e Arte das Bucólicas de Virgílio. Coimbra, Almedina.

Mendonça, F. (1997), “A Paixão do Conde Fróis”. Colóquio/Letras 99. Setembro-Outubro.

Mexia, P. (2005), “O Manuel Germano”. Diário de Notícias. Artes, 17 de Junho: http:// dn.sapo.pt/2005/06/17/artes/o_manuel_germano.html

Moisés, M. ('1973), A criação literária: introdução à Problemática da Literatura. São Paulo, Melhoramentos.

Mora, C. M. (2003), “A outra resposta de Tirésias”. In: Mora, C. M. (ed.), Sátira, Paródia e caricatura: da Antiguidade aos nossos dias. Aveiro, Universidade de Aveiro: 7-13.

Morais e Silva, A. (1953), Grande Dicionário da Lingua Portuguesa. Lisboa, Confluência.

Mourão, J. A. (1998), "Posfácio”, a Feijóo, Benito - Um Não Sei Quê. Lisboa, Vega.

Nickel, R. (1999), “Lucian's True Story: impressions of a fancy voyage”, Euphrosyne 27: 249-257.

Niederauer, S. (2008), "Era bom que trocássemos umas ideias sobre o assunto ou $\mathrm{O}$ simulacro da narrativa na pós-modernidade”. Letras de Hoje 43. 4: 83-88.

Oliveira, B. S. (1997), Eurípides. Hipólito. Brasília, Editora UNB.

Onelley, G. B. (2004), “A resistência da nau: cidade na luta pelo poder”. Calíope 12: 33-42.

Otte, G. (1996), "Rememoração e citação em Walter Benjamin". Revista de Estudos de Literatura 4. Belo Horizonte, Centro de Estudos Literários (CEL), Faculdade de Letras da UFMG: 211-223.

Pereira, E. (2003), "Viagens na minha terra: ciladas da representação". Revista do Centro de Estudos Portugueses 23 n. 32: 61-68.

Pereira, S. M. (2008), “Poética dos sonhos e das visōes em estado de vigília - I”, Humanitas 60: 11-28.

Pereira, S. M. (2009), "Poética dos sonhos e das visōes em estado de vigília - II”, Humanitas 61: 5-18.

Perelman, C. O. (1993), O Império Retórico: Retórica e Argumentação. Tradução de Fernando Trindade e Rui Alexandre Grácio. Porto, Ediçóes Asa. 
Perrin-Naffakh. A.-M. (1996), "Le langage cliché: aveu d'usure ou pouvoir d'écho". Confluências 14: 7-14.

Perrone-Moisés, L. (1979), “A intertextualidade crítica”. Poétique. Revista de teoria e análise literárias. Trad. port. Clara C. Rocha. Coimbra, Almedina: 209-230.

Pimentel, C. S. (2001), "O latim nas literaturas portuguesa e francesa: instrumentos, métodos e agentes de ensino”, Ágora, Estudos Clássicos em Debate 3: 183-185.

Piwnik, M.-H. (1998), "Mário de Carvalho: crónica de um desfecho anunciado", Veredas 1, Porto: 317-325.

Piwnik, M.-H. (2004), “De Sienkiewicz a Mário de Carvalho: Duas construções da História”. In: Literatura e História. Actas do Colóquio Internacional, Porto, vol. II: 139-144.

Platão ( $\left.{ }^{12} 2010\right)$, República. Trad. Maria Helena da Rocha Pereira. Lisboa, Fundação Calouste Gulbenkian.

Préchac, F. (1987), Sénèque. Lettres a Lucilius, II. Paris, Les Belles Lettres.

Queirós, E. de (s./d.), Os Maias. Lisboa, Livros do Brasil.

Queirós, E. de (2000), O Crime do Padre Amaro. Ed. crítica de Carlos Reis e M. Rosário Cunha. Lisboa, IN-CM.

Rabaté, E. (1996), "Henri Michaux et le cliché: résistance et fascination”. Confluências 14: 61-75.

Raimond, M. (1989), Le Roman. Paris, Armand Colin.

Reis, C. (1996), "Mário de Carvalho. Incitação ao romance”. Jornal de Letras 28 Agosto: 22-23.

Reis, C. (1997), "Fábula”. In: Biblos-Enciclopédia Verbo das Literaturas de Lingua Portuguesa. Lisboa, São Paulo, Verbo: 462-463.

Reis, C. (2005), História crítica da literatura portuguesa, vol. IX (Do neorrealismo ao postmodernismo). Lisboa, Verbo: 287-318.

Reis, C., Macário Lopes, A. C. (72007), Dicionário de narratologia. Coimbra, Almedina.

Ricoeur, P. (1983), Temps et Récit. T.I. Paris, Ed. du Seuil.

Rio Torto, G. M. (1996), "Linguagem e clichê", Confluências 14: 159-175.

Robilliard, M.-A. (2002), Água em pena de pato de Mário de Carvalho. Um teatro do desencanto. Trad. port. Manuel Ruas. Lisboa, Editorial Caminho.

Rocha Pereira, M. H. (1955), Concepçōes Helénicas de felicidade no além: de Homero a Platão. Coimbra, Maranus.

Rocha Pereira, M. H. (1980), Poesia Grega Arcaica. Coimbra, Instituto de Estudos Clássicos.

Rocha Pereira, M. H. (1984), Estudos de História da Cultura Clássica, vol. II (Cultura Romana). Lisboa, Fundação Calouste Gulbenkian.

Rocha Pereira, M. H. ('1994), Romana - Antologia da Cultura Latina. Coimbra, Universidade de Coimbra. 
Rocha Pereira, M. H. ( $\left.{ }^{10} 2006\right)$, História da Cultura Clássica, I (Cultura Grega). Lisboa, Fundação Calouste Gulbenkian.

Rodrigues, L. G. (2005), “A Radioestesia”. In http://rprecision.logspot.com/2005/06/radiestesia.html Rose, M. A. (1979), Parody and meta-fiction. London, Croom Helm.

Sant'Anna, A. R. ('1985), Parodia, paráfrase \& cia. São Paulo, Ática.

Santos, R. B. (2009), Aspectos da Herança Clássica em Mário de Carvalho. Belo Horizonte, Faculdade de Letras da UFMG, 2009. [versão policopiada].

Saramago, J. (1989), História do Cerco de Lisboa. Lisboa, Caminho.

Saramago, J. (1990), "História e Ficção”. Jornal de Letras, Artes e Ideias, 6 de Março.

Schaeffer, J. M. (1992), L'art de l'àge moderne. L'esthétique et la philosophie de l'art du XVIIIème siècle à nos jours. Paris, Gallimard.

Schmidt, W. (1963), Der Deus Ex Machina bei Euripides. Tübingen University.

Schwartz, J. (1981), Murilo Rubião: A poética do Uroboro. São Paulo, Editora Ática.

Scodel, R. (1999), Credible impossibilities. Conventions and strategies of verisimilitude in Homer and Greek tragedy. University of Michigan Press.

Sedlmayer, S., "Sinais de fogo, aviso de incêndio: ideias estéticas, históricas e literárias em Jorge de Sena e Walter Benjamin”. In: Revista Literatrua e Autoritarismo. Dossiê Walter Benjamin e a Literatura brasileira. Santa Maria, Universidade Federal de Santa Maria/ RS. Disponível em http://w3.ufsm.br/grpesqla/revista/dossie05/art_02.php

Seel, M. (1992), "Le langage de l'art est muet". In: Bouchindhomme, Ch., Rochlitz, R. (eds.), L'art Sans Compas. Redéfinitions de l'Esthétique. Paris, Éd. du Cerf.

Segurado e Campos, J. A. (1991), Cartas a Lucílio, Lisboa, Fundação Calouste Gulbenkian.

Seixo, M. A. (1995), "Mário de Carvalho. Romance, Humanismo e BD”, JL - Jornal de Letras, Artes e Ideias, 12. 4: 24-25.

Sena, J. http://www.letras.ufrj.br/lerjorgedesena/port/antologia/ficcao-e-teatro/texto.php?id=319

Sequeira, M. G. R. (1996), Aproximação a uma Leitura do Risivel em A Paixão do Conde de Fróis. Tese de Mestrado apresentada à Faculdade de Letras da Universidade do Porto (dact.).

Settis, S. (2006), El futuro de lo 'clásico'. Traducción de Andrés Soria Olmedo. Madrid, Abada Editores.

Silva, M. F. (1987), Critica do teatro na comédia antiga. Coimbra, INIC.

Silva, M. F. (2005), Ensaios sobre Euripides. Lisboa, Cotovia.

Silva, M. F. (2007), "A porta na comédia de Aristófanes: uma entrada para a utopia”. In: Ensaios sobre Aristófanes. Lisboa, Cotovia: 257-274. 
Silva, M. F. (2008), "Mensagens, cartas e livros no teatro grego antigo", in Matos, M. C. (ed.), Helénicos. Estudos em homenagem do Prof. Jean-Pierre Vernant (1914-2007). Lisboa, Ediçôes Távola Redonda: 227-260.

Silva, M. F. (2009), Utopias e distopias. Coimbra, Imprensa da Universidade.

Silvestre, O. M. (1998), "Mário de Carvalho: Revolução e Contra-revolução ou um passo atrás e dois à frente”. Colóquio/Letras 147/148: 209-229.

Silvestre, O. e Diogo, A. L. (1998), "Entrevista a Mário de Carvalho", in <http://www. ciberkiosk.pt>, arquivo, $\mathrm{n}^{\circ} 1$ (15 pp.).

Simões, M. J. (2006), “Atrevidas e desbordantes: as personagens em Mário de Carvalho”. In Figuras da Fiç̧ão. Coimbra, Centro de Literatura Portuguesa: 79-92.

Spivak, G. Ch. ('2003), “Can the subaltern speak?” In: Asheroft, B., Griffith, G., Tiffin, H. (eds.), The post-colonial studies reader. New York, Routledge.

Spivak, G. Ch. (1998), "Puede hablar elsujeto subalterno?”. Orbis Tertius 3. 6: 1-44.

Sterne, L. (1860), The Works of Lawrence Sterne. London, Henry Bohn.

Thomasson, A. (2003), "Fictional Characters and Literary Practices". British Journal of Aesthetics 43. 2, April:138-157.

Todorov, T. (1999), O homem desenraizado. Trad. Christina Cabo. Rio de Janeiro, Record.

Torrão, J. M. N. (ed.) (1999), III Colóquio Clássico. Aveiro, Universidade de Aveiro.

Tosi, R. (2000), Dizionario delle sentenze latine e greche. Milano, Biblioteca Universale Rizzoli.

Trindade, L. (2004), “Os excessos de Abril”, História 65: 20-31.

Valente, A. M. (2004), Aristóteles. Poética. Lisboa, Gulbenkian.

Várzeas, M. (2001), Silêncios no teatro de Sófocles, Lisboa, Cosmos.

Villeneuve, F. (1970), Horace. Odes et Epodes, I. Paris, Les Belles Lettres.

Xavier, L. G. (2007), O discurso da ironia. Lisboa, Novo Imbondeiro.

Walton, K. (1990), Mimesis as Make-Believe: On the Foundations of the Representational Arts. Cambridge Mass., Havard University Press.

Waugh, P. (2003), Metafiction. The Theory and Practice of Self-Conscious Fiction. London \& New York, Routledge [1984].

Wesseling, E. (1991), Writing History as a Prophet. Postmodernist Innovations of the Historical Novel. Amsterdam/Philadelphia, John Benjamins.

Wolff, F. (2004), “Quem é bárbaro?”. In: Novaes, A. (ed.), Civilização e Bárbarie. São Paulo, Companhia das Letras: 19-43.

Woods, J. (1974), The Logic of Fiction. Paris, Mouton; (2010), A Mecânica da fiç̧âo. Lisboa: Quetzal. Zagajewski, A. (2003), En la belleza ajena, trad. esp. A. E. Diaz-Pintado Hilario, Valencia, Pre-Textos. 